\title{
MAYA INDEX DAN KEPADATAN LARVA AEDES AEGYPTI ANTARA DUSUN TEGALREJO DAN DUSUN KRAJAN KIDUL NANGGUNGAN PACITAN
}

\author{
MAYA INDEX AND THE DENSITY OF AEDES AEGYPTI LARVAE BETWEEN \\ TEGALREJO VILLAGE AND KRAJAN KIDUL NANGGUNGAN VILLAGE PACITAN
}

\author{
Yelly Atiefsa Narmala ${ }^{1}$, R. Azizah ${ }^{1}$ \\ ${ }^{1}$ Departemen Kesehatan Lingkungan \\ Fakultas Kesehatan Masyarakat, Universitas Airlangga, Surabaya, Indonesia \\ Alamat Korespondensi: Yelly Atiefsa Narmala \\ Email:yellynarmala92@gmail.com
}

\begin{abstract}
Dengue fever remains a public health problem. Environmental factors influence the mosquito Aedes aegypti's growth, especially if there are many containers in the neighborhood. The community of Nanggungan Village have a habit of storing water in containers, therefore, they risk to become breeding sites for mosquitoes. This study aims to identify the Maya Index status of Aedes aegypti between Tegalrejo and Krajan Kidul Village. The research was observational with a cross-sectional design. Total samples were 200 homes, which 100 homes from Tegalrejo and 100 homes from Krajan Kidul Village, taken by simple random sampling. The measurement of variables employed observation sheet and analyzed in a descriptive approach. The number of containers observed in the Tegalrejo Village was 394 units, and Karajan Kidul Village was 391 units. Maya Index statuses in Tegalrejo (92\%) and Krajan Kidul Village (88\%) were low. Maya Index status in Krajan Kidul (13\%) was higher than Tegalrejo Village (8\%). House Index (HI) in the Tegalrejo (18.0\%) was lower than Krajan Kidul Village (25.0\%), Container Index in Tegalrejo (5.30\%) was lower than in Krajan Kidul Village (8.95\%), Breteau Index in Tegalrejo (21.0\%) was lower than in Krajan Kidul Village (35.0\%), Density Figure in Tegalrejo and Krajan Kidul Village indicated a scale of 3 and 4. Based on the MI's status, Tegalrejo and Krajan Kidul Village were included as a low-risk category of mosquito breeding sites. Based on the density number of larvae, two villages have a moderate risk of Dengue Fever transmission. The community should implement the Mosquitoes Breeding Sites Eradication Program (PSN $3 M$ Plus) and minimize the presence of the containers.
\end{abstract}

Keywords: Maya index, larvae density, container

\begin{abstract}
ABSTRAK
Demam Berdarah Dengue masih menjadi masalah kesehatan masyarakat. Faktor lingkungan berpengaruh terhadap perkembangan nyamuk Aedes aegypti, terutama bila di lingkungan terdapat banyak kontainer. Masyarakat Desa Nanggungan memiliki kebiasaan menyimpan air di dalam kontainer, sehingga berisiko menjadi tempat perkembang biakannyamuk. Penelitian ini bertujuan mengidentifikasi gambaran Maya Index Aedes aegypti antara Dusun Tegalrejo dengan Dusun Krajan Kidul. Jenis penelitian observasional, rancang bangun cross sectional. Jumlah sampel 200 rumah, 100 rumah dari Dusun Tegalrejo dan 100 rumah dari Dusun Krajan Kidul. Pengambilan sampel menggunakan metode Purposive Sampling. Pengukuran variabel menggunakan lembar observasi dan dianalisa secara deskriptif. Jumlah kontainer teramati sebesar 394 buah di Dusun Tegalrejo dan 391 buah di Dusun Krajan Kidul. Status Maya Index di Dusun Tegalrejo (92\%) dan Dusun Krajan Kidul (88\%) adalah rendah. Status Maya Indexs sedang di Dusun Krajan Kidul (13\%) lebih tinggi dibandingkan Dusun Tegalrejo (8\%). House Index (HI) di Dusun Tegalrejo (18,0\%) lebih rendah dibandingkan Dusun Krajan Kidul (25,0\%), Container Index di Dusun Tegalrejo (5,30\%) lebih rendah dibandingkan Dusun Krajan Kidul $(8,95 \%)$, Breteau Index di Dusun Tegalrejo (21,0\%) lebih rendah dibandingkan Dusun Krajan Kidul (35,0\%), Density Figure di Dusun Tegalrejo dan Dusun Krajan Kidul memiliki skala 3 dan 4. Berdasarkan status MI Dusun Tegalrejo dan Dusun Krajan Kidul masuk dalam kategori berisiko rendah sebagai tempat perkembangbiakan nyamuk. Berdasarkan angka kepadatan jentik kedua dusun memiliki risiko penularan sedang terhadap DBD. Masyarakat sebaiknya melaksanakan PSN 3M Plus dan meminimalisir keberadaan kontainer.
\end{abstract}

Kata Kunci: maya index, kepadatan jentik, kontainer

\section{PENDAHULUAN}

\section{Demam Berdarah Dengue (DBD)} merupakan merupakan penyakit yang disebabkan oleh virus dengue dan penularannya ke manusia melalui perantara nyamuk Aedes aegypti. DBD di Indonesia masih menjadi masalah kesehatan masyarakat, bahkan sejak tahun 1968 hingga 
saat ini, dimana penyakit ini dapat menimbulkan berbagai dampak diantaranya dampak sosial dan dampak ekonomi. Dampak sosial yang ditimbulkan antara lain menimbulkan kepanikan dalam keluarga, kehilangan anggota keluarga dan berkurangnya usia harapan hidup masyarakat. Sedangkan dampak ekonomi yang timbul adalah biaya pengobatan yang harus dikeluarkan, kehilangan waktu kerja dan lain seperti transportasi serta perawatan. Penyakit DBD pertama kali ditemukan pada tahun 1968 di Surabaya dan Jakarta. Semakin lama jumlah kasus cenderung meningkat dan daerah penyebarannya semakin luas, yaitu pada tahun 2013 penyakit DBD telah tersebar di 33 provinsi di Indonesia dan 436 kabupaten/kota (88\%) (Dirjen PP\&PL, 2012 dan Dirjen PP\&PL, 2014).

Salah satu daerah penyebaran penyakit
DBD adalah Kabupaten Pacitan. Berdasarkan data dari Dinas Kesehatan Pacitan, pada tahun 2014 terdapat 266 kasus dan pada tahun 2015 terjadi peningkatan jumlah kasus menjadi 917 kasus. Kasus DBD semakin meningkat hingga bulan September 2016, data menunjukkan angka 1149 kasus di Pacitan, dimana wilayah kerja Puskesmas Tanjungsari Kecamatan Pacitan merupakan wilayah yang paling tinggi kejadian DBD, yaitu pada tahun 2014 terdapat sejumlah 172 kasus dan meningkat menjadi 390 kasus pada tahun 2015. Selanjutnya data kasus DBD pada tahun 2016 (hingga September) mengalami penurunan menjadi 325 kasus.

Demam Berdarah Dengue (DBD) merupakan penyakit yang berbasis lingkungan, faktor lingkungan sangat berpengaruh terhadap perkembangan nyamuk Aedes aegypti, terutama bila di lingkungan tersebut terdapat banyak kontainer yang menjadi breeding place bagi nyamuk Aedes aegypti seperti bak mandi/WC, gentong, kaleng bekas, dan lainlain. Kontainer yang berisi air jernih dan terlindung dari sinar matahari langsung merupakan tempat per-kembangbiakan nyamuk Aedes aegypti terutama bila lokasinya di dalam dan dekat rumah (Soegijanto,2006).

Keberadaan kontainer berperan penting dalam peningkatan kepadatan vektor Aedes aegypti, karena semakin banyak jumlah kontainer yang ada di suatu wilayah maka semakin banyak pula tempat yang digunakan sebagai breeding place nyamuk Aedes aegypti. Hal tersebut dapat memudahkan vektor Aedes aegypti untuk berkembang biak, sehingga populasi nyamuk tersebut akan terus meningkat (Dinata dan Dhewantara, 2012).

Kebiasaan masyarakat di Indonesia dalam menggunakan kontainer untuk menyimpan air juga perlu diperhatikan. Penggunaan kontainer oleh masyarakat baik itu kontainer permanen maupun yang tidak permanen di daerah iklim tropis seperti di Indonesia merupakan salah satu faktor risiko yang dapat mempengaruhi perkembangan vektor Aedes aegypti. Menurut Sukana (1993), di Indonesia diperkirakan setiap rumah memiliki kontainer sebagai tempat penampungan air antara 5-6 buah. Perilaku masyarakat dalam menyimpan air sangat dipengaruhi oleh budaya setempat dan kebutuhan masyarakat akan air bersih. Sehingga hal itu dapat meningkatkan Controllable container yang dapat digunakan sebagai breeding place nyamuk Aedes aegypti.

Pengendalian DBD hingga saat ini lebih banyak ditekankan pada upaya memutus rantai penularan yaitu pada fase larva/jentik, karena gambaran jumlah larva/jentik dapat menunjukkan jumlah populasi vektor Aedes aegypti. Indikator yang digunakan untuk mengukur risiko penularan penyakit DBD adalah kepadatan jentik yaitu dengan mempertimbangkan angka HI, CI dan BI di suatu wilayah. Selain itu diperlukan juga data lingkungan yang terkait dengan bionomik nyamuk Aedes aegypti, yaitu Maya Index. Bionomik adalah hubungan aktivitas dan perilaku nyamuk dalam kesehariannya di lingkungan (Sigarlaki.,dkk, 2016).

Maya index adalah indikator yang digunakan untuk mengidentifikasi suatu 
daerah berisiko tinggi sebagai tempat perkembangbiakan vektor Aedes aegypti berdasarkan status kebersihan lingkungan HRI (Hygiene Risk Indicator) dan keberadaan tempat yang berpotensi sebagai tempat perkembangbiakan nyamuk BRI (Breeding Risk Indicator) (Danies-Lozano, 2002 dalam Dinata dan Dhewantara, 2015). Penelitian Purnama dan Baskoro (2012) di Kecamatan Denpasar menunjukkan bahwa maya index pada kasus lebih tinggi dibandingkan dengan kontrol, serta ada hubungan antara maya index dengan kejadian DBD.

Desa Nanggungan Pacitan sebagian masyarakat memiliki kebiasaan menyimpan air di dalam kontainer seperti gentong, ember, drum, dan sejenisnya untuk mengendapkan air bersih yang berasal dari sumur dan mengendapkan air yang telah dimasak untuk dikonsumsi. Selain itu masih ditemukan pula keberadaan kaleng bekas, botol bekas di lingkungan sekitar, serta terdapat ember bekas yang digunakan sebagai tempat untuk menampung air hujan. Hal tersebut apabila tidak diperhatikan dapat berpengaruh terhadap controllable container dan disposible container, sehingga dapat menjadi faktor risiko sebagai tempat perkembangbiakan vektor Aedes aegypti. Oleh karena itu perlu dilihat indikator maya index dan kepadatan jentik di wilayah tersebut. Penelitian ini bertujuan untuk mengidentifikasi maya index dan angka kepadatan jentik Aedes aegypti di Dusun Tegalrejo dan Dusun Krajan Kidul Pacitan.

\section{METODE PENELITIAN}

Penelitian ini merupakan penelitian observasional , karena pada obyek yang diteliti hanya dilakukan pengamatan dan wawancara, tanpa diberi perlakuan atau intervensi. Rancang bangun penelitian ini adalah cross sectional, kemudian hasilnya dianalisis secara deskriptif.Populasi dalam penelitian ini adalah seluruh rumah di dusun yang ada jumantik (Dusun Tegalrejo)dan seluruh rumah di dusun yang tidak ada jumantik (Dusun Krajan Kidul). Besar sampel adalah 100 rumah di Dusun Tegalrejo dan 100 rumah di Dusun Krajan Kidul Pacitan. Teknik pengambilan sampel yang digunakan adalah Purposive sampling. Pengambilan data dilakukan dengan cara mengamati jenis kontainer, jumlah kontainer, dan keberadaan jentik di dalam kontainer. Pengamatan jentik dilakukan dengan metode visual yaitu dengan melihat ada atau tidaknya jentik di setiap tempat genangan air tanpa mengambil jentiknya. Alat yang digunakan untuk observasi adalah menggunakan senter dan lembar observasi. Setelah pengamatan dilakukan selanjutnya hasilnya di catat pada lembar observasi. Kemudian dikategorikan menjadi Controllable containers (CC) dan Disposable containers (DC). Controllable containers adalah tempat yang terkontrol atau dapat dikendalikan oleh manusia agar vektor tidak dapat berkembang biak seperti bak mandi, tempat minum burung, ember,drum, dan sejenisnya.Penelitian ini telah memperoleh keterangan lolos kaji etik dari Komisi Etik FKM No : 105-KEPK.

Tabel 1. Matriks 3x3 Komponen BRI dan HRI pada Maya Index

\begin{tabular}{|c|c|c|c|c|}
\hline & & & 3RI & \\
\hline & & $\begin{array}{c}1 \\
\text { (Rendah) }\end{array}$ & $\begin{array}{c}2 \\
\text { (Sedang) } \\
\end{array}$ & $\begin{array}{c}3 \\
\text { (Tinggi) } \\
\end{array}$ \\
\hline$\widetilde{a}$ & $\begin{array}{c}1 \\
\text { (Rendah) }\end{array}$ & BRI1/HRI1 & BRI2/HRI1 & BRI3/HRI1 \\
\hline $\boldsymbol{I}$ & $\begin{array}{c}2 \\
\text { (Sedang) }\end{array}$ & BRI1/HRI2 & BRI3/HRI2 & BRI3/HRI2 \\
\hline & $\begin{array}{c}3 \\
\text { (Tinggi) }\end{array}$ & BRI1/HRI3 & BRI3/HRI3 & BRI3/HRI3 \\
\hline
\end{tabular}


Sumber : Miller,J., dkk (1992) dalam Dhewantara dan Dinata (2015)

Tabel 2. Indeks Kepadatan Jentik

\begin{tabular}{cccc}
\hline $\begin{array}{c}\text { Tingkat Kepadatan } \\
\text { (DF) }\end{array}$ & $\begin{array}{c}\text { House Index } \\
(\mathbf{H I})\end{array}$ & Container Index (CI) & Breteu Index (BI) \\
\hline 1 & $1-3$ & $1-2$ & $1-4$ \\
2 & $4-7$ & $3-5$ & $5-9$ \\
3 & $8-17$ & $6-9$ & $10-19$ \\
4 & $18-28$ & $10-14$ & $20-34$ \\
5 & $29-37$ & $15-20$ & $35-49$ \\
6 & $38-49$ & $21-27$ & $50-74$ \\
7 & $50-59$ & $28-31$ & $75-99$ \\
8 & & & $100-199$ \\
9 & $60-76$ & $32-40$ & $200+$ \\
\hline
\end{tabular}

Sumber : Queensland Goverment (2011) dalam Ariva dan Oginawati (2013)

Disposable containers (DC) adalah tempat/wadah yang sudah tidak terpakai dan keberadaannya berpotensi menampung air hujan sehingga dapat digunakan sebagai breeding place nyamuk Aedes aegypti seperti kaleng bekas, ban bekas, ember bekas, dan sejenisnya (Dinata dan Dhewantara, 2015). Data yang diperoleh kemudian dianalisis secara deskriptif yaitu menggambarkan Maya Index dan angka kepadatan jentik di Dusun Tegalrejo dan Dusun Krajan Kidul. Perhitungan Maya Index dilakukan untuk mengetahui apakah di suatu wilayah berisiko tinggi sebagai tempat perkembangbiakan larva (larval breeding risk) berdasarkan kebersihan dan ada/ tidaknya tempat yang dapat menjadi perkembangbiakan nyamuk. Indikator yang digunakan untuk menentukan Maya Index adalah Breading Risk Indicator (BRI) yaitu indikator risiko tempat perkembangbiakan nyamuk, yang diperoleh dengan cara membagi jumlah Controllable container (CC) tiap rumah dengan rata-rata $\mathrm{CC}$ positif larva, dan Hygiene Risk Indicator (HRI) yaitu risiko kebersihan lingkungan, yang diperoleh dengan cara membagi Disposable container (DC) tiap rumah dengan rata-rata DC yang positif larva. Selanjutnya indikator
HRI dan BRI tersebut dikategorikan menjadi kategori rendah, sedang, dan tinggi berdasarkan distribusi tertiles dengan rumus Rendah : $\mathrm{x}<(\mu-1,0$ SD $)$

Sedang : $(\mu-1,0$ SD $) \leq x>(\mu+1,0$ SD $)$ Tinggi $: x>(\mu+1,0$ SD $)$

Nilai BRI dan HRI tiap rumah selanjutnya disusun dalam matrik $3 \times 3$ untuk menentukan kategori Maya Index. Selanjutnya indikator yang digunakan untuk mengetahui kepadatan jentik Aedes aegypti adalah House Index (HI), Container Index (CI), dan Breteau Index (BI) dengan rumus sebagai berikut :

$$
\begin{aligned}
& \mathrm{HI}=\frac{\text { Jumlahrumahpositif jentik }}{\text { Jumlahrumahyangdiperiksa }} \times 100 \\
& \mathrm{CI}=\frac{\text { Jumlahkontainerpositifjentik }}{\text { Jumlahkontaineryangdiperiksa }} \times 100 \\
& \mathrm{BI}=\frac{\text { Jumlahkontainerpositifjentik }}{100 \text { rumahyangdiperiksa }} \times 100 \%
\end{aligned}
$$

Kepadatan jentik (Density Figure) dihitung dengan cara menggabungkan hasil HI, CI, BI sehingga diperoleh kategori tingkat kepadatan jentik seperti pada Tabel 2:

DF dapat dibagi dalam 3 kategori yaitu:

1. Kepadatan rendah jika DF $=1$

2. Kepadatan sedang jika DF $=2-5$ 
3. Kepadatan tinggi jika $\mathrm{DF}=6-9$

\section{HASIL}

Tabel 3 menunjukkan jumlah kontainer yang ditemukan pada rumah responden sebanyak 394 kontainer di Dusun Tegalrejo dan 391 kontainer di Dusun Krajan Kidul. Kontainer tersebut dibedakan menjadi controllable sites dan disposable sites (DS). Berdasarkan hasil survey, menunjukkan bahwa proporsi controllable sites(CS)lebih banyak ditemukan dibandingkan proporsi disposable sites (DS). Jumlah controllable sites di Dusun Krajan Kidul yang ditemukan sebanyak 339 buah $(86,7 \%)$ sedangkan di Dusun Tegalrejo sebesar 336 buah $(85,2 \%)$. Jenis kontainer controllable sites yang paling banyak ditemukan adalah bak mandi, dengan jumlah 95 buah (25,3\%) di Dusun Tegalrejo dan 92 buah $(27,1 \%)$ di Dusun Krajan Kidul. Selanjutnya jumlah disposable sites (DS) yang ditemukan di kedua dusun hampir sama yakni sebanyak 58 buah $(14,7 \%)$ di Dusun Tegalrejo dan 52 buah $(13,3 \%)$ di Dusun Krajan Kidul. Kaleng bekas merupakan kontainer disposable sites yang lebih banyak ditemukan yakni sebanyak 25 buah $(43,1 \%)$ di Dusun Tegalrejo dan 24 buah $(46,1 \%)$ di Dusun Krajan Kidul. Keberadaan jentik pada controllable sites lebih banyak ditemukan di bak mandi yakni sebesar 7 buah $(7,5 \%)$ dan 12 buah $(13,0 \%)$. Sedangkan pada kontainer disposable sites (DS), keberadaan jentik paling banyak ditemukan pada kaleng bekas sebesar $16 \%$ di Dusun Tegalrejo dan 12,5\% di Dusun Krajan Kidul.

Berdasarkan Tabel 4 menunjukkan bahwa sebanyak $89 \%$ dan $78 \%$ rumah responden di Dusun Tegalrejo dan Dusun Krajan Kidul masuk dalam kategori BRI rendah. Proporsi BRI tinggi pada rumah responden di Dusun Tegalrejo sebesar 6,0\% sedangkan di Dusun Krajan Kidul sebesar $10,0 \%$, hal ini menunjukkan bahwa BRI tinggi lebih banyak ditemukan pada rumah responden di Dusun Krajan Kidul. HRI di
Dusun Tegalrejo dan Dusun Krajan Kidul hampir sama yakni menunjukkan angka 98\% dan $97 \%$ termasuk dalam kategori rendah. Meskipun sebagian besar rumah di kedua dusun termasuk dalam kategori HRI rendah, namun perlu juga diperhatikan karena terdapat 2 rumah responden $(2,0 \%)$ di Dusun Tegalrejo dan 3 rumah responden (3,0\%) di Dusun Krajan Kidul masuk dalam kategori tinggi. HRI berkaitan dengan keberadaan kontainer yang tidak terpakai/disposabe sites (DS) dan menggambarakan risiko kebersihan lingkungan di rumah responden. Hasil tersebut menggambarkan bahwa masih terdapat $2,0 \%$ dan 3,0\% rumah responden di kedua dusun dengan kebersihan lingkungan yang masih rendah, sehingga dapat mempengaruhi status maya index di dusun tersebut.

Tabel 5 menunjukkan kategori maya index di Dusun Tegalrejo dan Dusun Krajan Kidul yang dibagi menjadi 3 kategori yakni rendah, sedang, tinggi. Berdasarkan hasil survey pada100 rumah di Dusun Tegalrejo dan 100 rumah di Dusun Krajan Kidul menunjukkan bahwa terdapat 92 rumah (92\%) di dusun Tegalrejo dan 88 rumah (88\%) di Dusun Krajan Kidul termasuk dalam status Maya Index(MI) rendah karena memenuhi syarat BRI1/HRI1, BRI1/HRI2, dan BRI2/HRI1.

Terdapat 8 rumah $(8 \%)$ di Dusun Tegalrejo dan 13 rumah $(13,0 \%)$ di Dusun Krajan Kidul masuk dalam status Maya index (MI) sedang karena memenuhi kriteria BRI3/HRI1 dan BRI1/HRI3. Hasil tersebut menggambarkan status maya index sedang di Dusun Krajan Kidul lebih tinggi dibandingkan Dusun Tegalrejo Berdasarkan Tabel 6 menunjukkan bahwa terdapat angka HI sebesar 18,0\%, CI sebesar 5,3\%, dan BI sebesar $21,0 \%$. Setelah diperoleh nilai dari tiap indeks, kepadatan jentik (Density Figure) diperoleh dari gabungan nilai HI, CI, dan BI yang dinyatakan dalam skala 1 9. 
Tabel 3. Distribusi Jenis Kontainer dan Keberadaan Jentik Aedes aegypti di Dusun Tegalrejo dan Dusun Krajan Kidul Pacitan 2016

\begin{tabular}{|c|c|c|c|c|c|c|}
\hline \multirow[b]{2}{*}{ Jenis Kontainer } & \multicolumn{3}{|c|}{ Dusun Tegalrejo } & \multicolumn{3}{|c|}{ Dusun Krajan Kidul } \\
\hline & $\begin{array}{c}\text { Jumlah } \\
\text { diperiksa }\end{array}$ & $\begin{array}{l}\text { Positif } \\
\text { Jentik }\end{array}$ & $\%$ & $\begin{array}{c}\text { Jumlah } \\
\text { diperiksa }\end{array}$ & $\begin{array}{l}\text { Positif } \\
\text { Jentik }\end{array}$ & $\%$ \\
\hline Controllable Sites & 336 & 16 & $4,8 \%$ & 339 & 32 & $9,4 \%$ \\
\hline a. Bak mandi & 95 & 7 & $7,5 \%$ & 92 & 12 & $13,0 \%$ \\
\hline b. Bak WC & 41 & 2 & $4,9 \%$ & 36 & 3 & $8,3 \%$ \\
\hline c. Drum & 5 & 1 & $20 \%$ & 6 & 1 & $16,7 \%$ \\
\hline d. Tempayan & 42 & 3 & $7,1 \%$ & 56 & 5 & $8,9 \%$ \\
\hline e. Ember & 44 & 3 & $6,8 \%$ & 67 & 8 & $11,9 \%$ \\
\hline $\begin{array}{l}\text { f. Tempat penadah air } \\
\text { dispenser }\end{array}$ & 18 & 0 & 0,0 & 14 & 0 & 0,0 \\
\hline $\begin{array}{l}\text { g. Tempat penadah air } \\
\text { kulkas }\end{array}$ & 55 & 0 & 0,0 & 35 & 0 & 0,0 \\
\hline h. Pot tanaman hias & 22 & 0 & 0,0 & 14 & 0 & 0,0 \\
\hline i. Tatakan pot & 4 & 0 & 0,0 & 0 & 0 & 0,0 \\
\hline j. Tempat wudhu & 2 & 0 & 0,0 & 6 & 3 & $50 \%$ \\
\hline $\begin{array}{l}\text { k. Tempat minum } \\
\text { burung }\end{array}$ & 8 & 0 & 0,0 & 13 & 0 & 0,0 \\
\hline Disposable Sites & 58 & 5 & $8,6 \%$ & 52 & 3 & $5,8 \%$ \\
\hline a. Kaleng bekas & 25 & 4 & $16 \%$ & 24 & 3 & $12,5 \%$ \\
\hline b. Ban bekas & 7 & 1 & $14,3 \%$ & 2 & 0 & 0,0 \\
\hline c. Botol bekas & 10 & 0 & 0,0 & 13 & 0 & 0,0 \\
\hline d. Pecahan piring & 4 & 0 & 0,0 & 6 & 0 & 0,0 \\
\hline e. Pecahan mangkok & 3 & 0 & 0,0 & 3 & 0 & 0,0 \\
\hline f. Pecahan gelas & 3 & 0 & 0,0 & 2 & 0 & 0,0 \\
\hline g. Bekas akuarium & 2 & 0 & 0,0 & 1 & 0 & 0,0 \\
\hline $\begin{array}{l}\text { h. Bekas kolam ikan } \\
\text { dari semen }\end{array}$ & 4 & 0 & 0,0 & 1 & 0 & 0,0 \\
\hline Jumlah & 394 & 21 & $5,3 \%$ & 391 & 35 & $8,9 \%$ \\
\hline
\end{tabular}

Berdasarkan hasil perhitungan tersebut, maka diketahui Density Figure (DF) di Dusun Tegalrejo masuk dalam skala 3 sehingga dapat dikatakan Dusun Tegalrejo termasuk dalamkategori kepadatan sedang. Dusun Krajan Kidul, berdasarkan perhitungan diperoleh angka HI sebesar
25,0\% CI sebesar 8,9\% dan BI sebesar $35,0 \%$. Berdasarkan perhitungan indeks $\mathrm{HI}$, CI, dan BI selanjutnya diperoleh Density Figure (DF) dengan skala 4 dapat dikatakan Dusun Krajan Kidul termasuk dalam kategori kepadatan sedang.

Tabel 4. Distribusi Rumah Berdasarkan Berdasarkan BRI dan HRI di Dusun Tegalrejo dan Dusun Krajan Kidul Nanggungan Pacitan 2016

\begin{tabular}{lcccc}
\hline \multirow{2}{*}{ Kategori } & \multicolumn{2}{c}{ Breeding Risk Index } & \multicolumn{2}{c}{ Hygiene Risk Index } \\
\cline { 2 - 5 } & $\begin{array}{c}\text { Dusun } \\
\text { Tegalrejo }\end{array}$ & $\begin{array}{c}\text { Dusun } \\
\text { Krajan Kidul }\end{array}$ & $\begin{array}{c}\text { Dusun } \\
\text { Tegalrejo }\end{array}$ & $\begin{array}{c}\text { Dusun Krajan } \\
\text { Kidul }\end{array}$ \\
\hline Rendah & $89(89,0 \%)$ & $78(78,0 \%)$ & $98(98,0 \%)$ & $97(97,0 \%)$ \\
Sedang & $5(5,0 \%)$ & $12(12,0 \%)$ & $0(0,0 \%)$ & $0(0,0 \%)$ \\
Tinggi & $6(6,0 \%)$ & $10(10,0 \%)$ & $2(0,0 \%)$ & $3(3,0 \%)$ \\
\hline Total & 100 & 100 & 100 & 100 \\
\hline
\end{tabular}


Tabel 5. Matriks 3x3 Kombinasi Breeding Risk Indicator dan Hygiene Risk Indicator di Dusun Tegalrejo dan Dusun Krajan Nanggungan Pacitan 2016

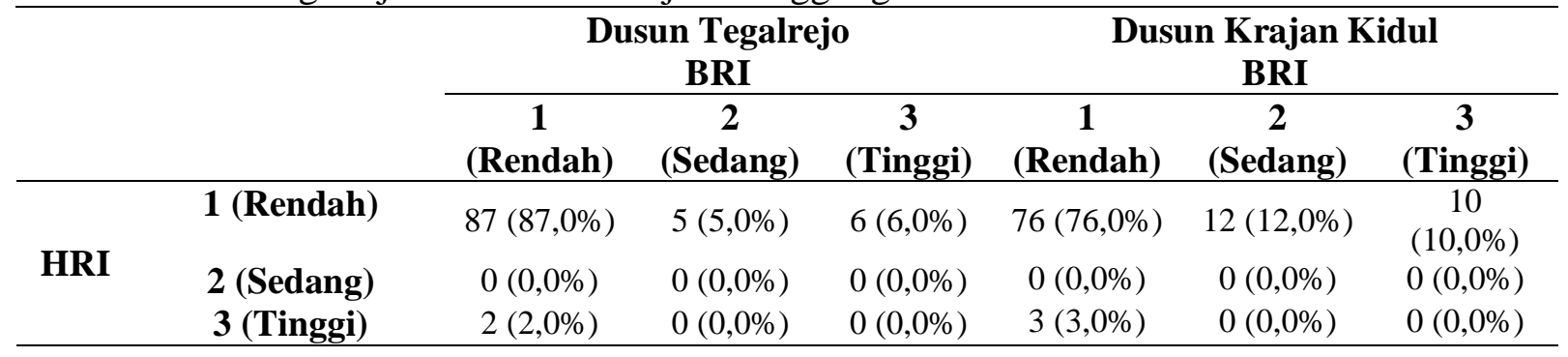

Tabel 6. Angka Kepadatan Jentik antara Dusun Tegalrejo dan Dusun Krajan Kidul Pacitan 2016

\begin{tabular}{lcccccccc}
\hline & \multicolumn{3}{c}{ Rumah } & \multicolumn{2}{c}{ Kontainer } & \multicolumn{3}{c}{ Indeks Kepadatan Jentik } \\
\cline { 2 - 9 } Dusun & $\begin{array}{c}\text { Jumlah } \\
\text { diperiksa }\end{array}$ & $\begin{array}{c}\text { Ada } \\
\text { jentik } \\
(+)\end{array}$ & $\begin{array}{c}\text { Jumlah } \\
\text { diperiksa }\end{array}$ & $\begin{array}{c}\text { Ada } \\
\text { jentik } \\
(+)\end{array}$ & $\begin{array}{c}\text { HI } \\
(\boldsymbol{\%})\end{array}$ & $\begin{array}{c}\text { CI } \\
(\boldsymbol{\%})\end{array}$ & $\begin{array}{c}\text { BI } \\
(\boldsymbol{\%})\end{array}$ & $\begin{array}{c}\text { Density } \\
\text { Figure } \\
(\mathbf{D F})\end{array}$ \\
\hline Dusun Tegalrejo & 100 & 18 & 394 & 21 & 18,0 & 5,3 & 21,0 & 3 \\
Dusun Krajan Kidul & 100 & 25 & 391 & 35 & 25,0 & 8,9 & 35,0 & 4 \\
\hline
\end{tabular}

Hasil penelitian ini sejalan dengan penelitian yang dilakukan oleh Purnama dan Baskoro (2012) di Bali yaitu diperoleh angka kepadatan jentik sebesar 4 dan masuk dalam kategori penularan sedang.

\section{PEMBAHASAN}

Hasil penelitian menggambarkan bahwa sebagian besar rumah responden di Dusun Tegalrejo dan Dusun Krajan Kidul menunjukkan status Maya Index (MI) masuk dalam kategori rendah. Namun hal itu tetap harus diperhatikan karena masih terdapat beberapa rumah responden yang menunjukkan status MI nya masuk dalam kategori sedang. Keberadaan kontainer dan kebersihan lingkungan sangat berpengaruh terhadap keberadaan dan kepadatan nyamuk Aedes aegypti di lingkungan tempat tinggal masyarakat (Astuti.,dkk 2016). Penelitian ini menggambarkan bahwa sebagian besar kontainer yang ditemukan adalah controllable sites dan keberadaan jentik lebih banyak ditemukan pada kontainer yang mudah dikendalikan (controllable sites), hasil penelitian ini sejalan dengan penelitian Dhewantara dan Dinata di Kota Banjar yang menunjukkan bahwa sebesar 92,8\% kontainer yang ditemukan adalah controlable sites dan keberadaan jentik lebih banyak ditemukan pada controllable sites.

Penelitian ini sekaligus sejalan dengan penelitian Astuti.,dkk (2016) di Kota Tangerang Selatan yaitu sebanyak 94,3\% adalah kontainer yang terkontrol masyrakat dan kontainer positif jentik yang banyak ditemukan adalah pada controllable sites. Banyaknya jumlah controllable sites dan banyaknya jumlah CS positif jentik yang ditemukan di kedua dusun di-karenakan masyarakatnya masih memiliki kebiasaan menyimpan air bersih baik itu air hujan maupun air sumur di dalam ember, gentong, drum dan sejenisnya. Sebagian besar masyarakat menggunakan air sumur bor untuk memenuhi kebutuhan sehari-hari, dimana air yang keluar kondisinya sangat keruh sehingga masyarakat memiliki kebiasaan mengendapkan air terlebih dahulu sebelum digunakan, sehingga dapat mempengaruhi jumlah CS dan memudahkan nyamuk Aedes aegypti untuk berkembang biak di kontainer tersebut. Selain itu terdapat pula masyarakat yang menampung air hujan di drum atau ember sebagai persediaan air untuk memberikan minum pada hewan ternak seperti sapi/kambing. 
Berdasarkan hasil penelitian, menunjukkan bahwa bak mandi merupakan jenis kontainer yang paling banyak positif jentik dibandingkan kontainer yang lain, hal ini sejalan dengan penelitian Dhewantara dan Dinata (2015) di Kota Banjar yang menunjukkan tempat penampungan air yang lebih banyak positif jentik Aedes aegypti adalah berada di bak mandi. Dhewantara dan Dinata (2015) menambahkan bahwa bak air merupakan kontainer kunci (key container) yang berperan dalam perkembangbiakan vektor DBD. Umumnya bak mandi berada di dalam rumah, terlindung dari sinar matahari dan berisi air jernih sehingga disukai nyamuk Aedes aegypti sebagai tempat perindukan. Hal ini sesuai dengan teori Sogiejanto (2006) bahwa nyamuk Aedes aegypti lebih menyukai tempat perindukan yang berwarna gelap, terlindung dari sinar matahari, permukaan terbuka lebar, dan berisi air tawar yang jernih. Sebagian besar masyarakat di kedua dusun masih menggunakan bak mandi permanen di dalam kamar mandi yang menyebabkan air di dalam bak mandi tidak langsung habis sekali pakai dan terkadang mengendap sampai berhari-hari, apabila perilaku masyarakat dalam menguras bak mandi tidak rutin maka hal ini dapat memudahkan nyamuk untuk berkembang biak di dalam bak mandi, sehingga dapat mempengaruhi indikator BRI.

Berdasarkan indikator HRI dan BRI yang tercantum pada Tabel 5, menunjukkan bahwa sebagian besar BRI di Dusun Tegalrejo maupun Dusun Krajan Kidul masuk dalam kategori rendah, hal ini menunjukkan bahwa sebagian besar rumah responden di Dusun Tegalrejo maupun di Dusun Krajan Kidul tidak berisiko menjadi tempat perkembangbiakan nyamuk. Namun, tetap harus diperhatikan karena masih terdapat beberapa rumah responden yang masuk dalam kategori BRI tinggi. BRI tinggi di Dusun Krajan Kidul sebesar 10\% lebih besar dibandingkan Dusun Tegalrejo. BRI berkaitan dengan keberadaan kontainer yang terpantau/ controllable sites (CS)dan menggambarkan banyaknya tempat per- kembangbiakan vektor. Tingginya indikator BRI di Dusun Krajan Kidul di karenakan banyak ditemukannya controllable sites di Dusun tersebut sehingga dapat berisiko menjadi tempat perkembangbiakan nyamuk. Berdasarkan Tabel 3, terbukti bahwa proporsi CS di Dusun Krajan Kidul lebih tinggi dibandingkan Dusun Tegalrejo. Oleh karena itu keberadaan CS di Dusun Tegalrejo dan Krajan Kidul perlu diperhatikan dan dijaga kebersihannya karena sangat berisiko menjadi tempat perindukan vektor DBD, dan pada kenyataannya masih banyak masyarakat yang memiliki kebiasaan menyimpan air.

HRI berkaitan dengan keberadaan kontainer yang tidak terpakai/disposable sites (DS) dan menggambarakan risiko kebersihan lingkungan di lingkungan rumah responden. Meskipun sebagian besar rumah di kedua dusun termasuk dalam kategori HRI rendah, namun terdapat 2 rumah responden $(2,0 \%)$ di Dusun Tegalrejo dan 3 rumah responden $(3,0 \%)$ di Dusun Krajan Kidul masuk dalam kategori tinggi. Hal ini perlu diperhatikan, meskipun jumlah rumah yang masuk HRI tinggi tidak banyak namun rumah tersebut sangat berisiko untuk perkembangbiakan nyamuk karena didukung oleh keberadaan tempat perkembangbiakan dan kurang bersihnya sanitasi lingkungan. Proporsi DS yang banyak ditemukan adalah kaleng bekas, keberadaan jentik juga lebih banyak ditemukan pada kaleng bekas. Hal ini dikarenakan masyarakat di kedua dusun memiliki kebiasaan menggunakan kaleng bekas untuk tempat minum hewan peliharaan, untuk menampung air hujan dan sebagai tempat air untuk mengasah arit/pisau, sehingga memungkinkan air tergenang ditempat tersebut dan memudahkan nyamuk Aedes aegypti untuk berkembang biak di tempat tersebut.

Hasil penelitian ini menggambarkan bahwa Maya indeks di dusun Krajan Kidul lebih tinggi dibandingkan Dusun Tegalrejo.Ini berarti Dusun Krajan Kidul lebih berisiko untuk menjadi tempat perkembangbiakan nyamuk dibandingkan 
dengan Dusun Tegalrejo. Purnama dan Baskoro yang menyatakan bahwa status MI tinggi pada kelompok kasus lebih besar dibandingkan pada kontrol dengan persentase $30,66 \%$. Tingginya status MI di Dusun Krajan Kidul dikarenakan di dusun ini memiliki jumlah kontainer yang tinggi. Keberadaan jentik juga banyak ditemukan pada CS di Dusun Krajan Kidul dibandingkan Dusun Tegalrejo. Jumlah kontainer lebih banyak terdapat di Dusun Tegalrejo namun status MI sedang justru banyak terdapat di Dusun Krajan Kidul, hal ini dikarenakan keberadaan jentik justru lebih banyak ditemukan di Dusun Krajan Kidul. Kurangnya kesadaran masyarakat dalam membersihkan kontainer yang berada di dalam maupun di luar rumahnya, sehingga sangat efektif sebagai tempat perkembangniakan nyamuk Aedes aegypti. Pratamawati (2012), bahwa perilaku sebagian besar masyarakat belum didasari kesadaran akan pentingnya memelihara kebersihan lingkungan. Kurang baiknya tindakan masyarakat dalam melaksanakan PSN DBD akan menciptakan lingkungan yang kondusif bagi per-kembangbiakan nyamuk Aedes aegypti.

Indikator lain yang dapat digunakan untuk mengukur tingkat risiko terjadinya penularan DBD adalah angka kepadatan jentik. Parameter yang digunakan untuk mengukur angka kepadatan jentik adalah HI, CI, dan BI. Berdasarkan Tabel 6 dapat dilihat bahwa angka HI di Dusun Tegalrejo sebesar 18,0\% dan di Dusun Krajan Kidul sebesar 25,0\%, artinya dalam 100 rumah yang diperiksa terdapat $18,0 \%$ dan $25,0 \%$ yang terdapat jentik. Meskipun angka HI di Dusun Krajan Kidul lebih tinggi dibandingkan Dusun Tegalrejo, namun keduanya sama masuk dalam kategori daerah risiko tinggi penularan DBD dikarenakan angka HI lebih besar dari 10\%, sejalan dengan Rokhmawanti dkk (2015), di Kelurahan Tegalsari Kota Tegal yang menunjukkan nilai sebesar $66,0 \%$.

Berdasarkan nilai container index (CI), CI di Dusun Tegalrejo (5,3\%) lebih rendah dibandingkan Dusun Krajan Kidul
(8,9\%). Selanjutnya nilai Breteau Index (BI) di Dusun Tegalrejo (21\%) lebih rendah dibandingkan Dusun Krajan Kidul (35\%). CI kedua dusun tersebut kurang dari $10 \%$ dan BI kurang dari 50\%, sehingga termasuk dalam kategori rendah, berbanding terbalik dengan penelitian Rokhmawanti.,dkk (2015), dimana diperoleh nilai CI dan BI masuk dalam kategori tinggi. Penelitian ini sejalan dengan penelitian Dhewantara dan Dinata (2015) di Kota Banjar yakni didapatkan angka CI sebesar 3,85\% dan BI sebesar 35\%. Meskipun nilai CI dan BI kurang dari $10 \%$ dan $50 \%$, namun tetap perlu diwaspadai karena sudah menunjukkan adanya potensi risiko penularan DBD, dikarenakan skala Density Figure menunjukkan kategori kepadatan sedang.

Berdasarkan Density Figure, kedua dusun menunjukkan hasil yang sama, yaitu DF terdapat pada skala 3 di Dusun Tegalrejo dan 4 di Dusun Krajan Kidul, sehingga dikatakan kedua dusun tersebut termasuk dalam kategori kepadatan sedang. Sejalan dengan penelitian Dhewantara dan Dinata (2015) di Kota Banjar dan Astuti.,dkk (2016) di Kota Tangerang Selatan yang menunjukkan risiko penularan DBD kedua daerah tersebut masuk dalam kategori sedang. Penelitian ini sejalan pula dengan penelitian Purnama dan Baskoro (2012) yang dilakukan di Bali menunjukkan bahwa angka House Index adalah 23,33\% dan Container Index sebesar 10,69\% memiliki Density Figure dengan skala 4, sehingga dapat diartikan bahwa daerah tersebut memiliki risiko penularan sedang terhadap penyebaran penyakit DBD. Kepadatan jentik merupakan faktor risiko terjadinya penularan DBD, artinya semakin tinggi kepadatan nyamuk Aedes aegypti, maka risiko masyarakat untuk tertular DBD juga semakin tinggi (Wati, 2009).

Keberadaan kontainer merupakan faktor risiko yang menyebabkan kepadatan jentik tinggi dan merupakan salah satu lingkungan fisik yang mempengaruhi kehidupan nyamuk Aedes aegypti. Keberadaan kontainer memiliki peran 
penting dalam peningkatan kepadatan vektor Aedes aegypti, karena semakin banyak jumlah kontainer yang ada di suatu wilayah maka semakin banyak pula tempat yang digunakan sebagai perindukan nyamuk Aedes aegypti. Hal tersebut akan memudahkan vektor Aedes aegypti dalam berkembang biak, sehingga populasi nyamuk tersebut akan terus meningkat. (Dinata dan Dhewantara, 2012). Apabila populasi vektor Aedes aegypti meningkat, maka kepadatan vektor Aedes aegypti juga semakin meningkat. Keberadaan kontainer pada kedua dusun menunjukkan bahwa terdapat banyak kontainer yang ditemukan di dusun Tegalrejo maupun Dusun Krajan Kidul karena masyarakat masih memiliki kebiasaan menyimpan air di dalam kontainer, sehingga hal ini perlu suatu upaya untuk mengelola kontainer sehingga dapat meminimalisir keberadaan jentik.

Keberadaan kontainer, kebersihan lingkungan dan keberadaan jentik sangat bergantung pada tindakan Pemberantasan Sarang Nyamuk (PSN). Terdapatnya rumah reponden dengan status Maya Index yang masih sedang dan angka kepadatan jentik yang masuk kategori penularan sedang di Dusun Tegalrejo maupun Dusun Krajan Kidul dimungkinkan karena masih kurangnya kesadaran masyarakat dalam melakukan PSN sehingga berpengaruh terhadap tindakannya dalam melakukan PSN. Pemberantasan Sarang Nyamuk (PSN) merupakan cara pengendalian vektor yang dilakukan dengan cara membasmi jentik Aedes aegypti melalui gerakan 3M Plus yaitu menguras tempat penampungan air sedikitnya satu minggu sekali, menutup rapat tempat penampungan air dan mengubur/mendaur ulang barang-barang bekas yang dapat menjadi tempat perkembangbiakan jentik nyamuk Aedes aegypti. Apabila praktik PSN baik maka kepadatan jentik dapat diturunkan dan ABJ dapat ditingkatkan. Menurut penelitian yang dilakukan oleh Widagdo., dkk (2008), menunjukkan bahwa ada hubungan antara PSN 3M Plus dengan kepadatan jentik.
Pemberantasan Sarang Nyamuk (PSN) merupakan kegiatan yang paling berpengaruh terhadap keberadaan jentik nyamuk di tempat penampungan air karena berhubungan secara langsung. Menurut Taviv., dkk (2010) seseorang yang melakukan praktik PSN 3M Plus dengan benar, maka keberadaan jentik nyamuk di dalam kontainer dapat berkurang atau bahkan hilang. Berdasarkan hal tersebut perlu adanya upaya penggerakan masyarakat di Dusun Tegalrejo dan Dusun Krajan Kidul untuk melakukan Pem-berantasan Sarang Nyamuk (PSN) 3M Plus untuk menekan angka kepadatan jentik

\section{SIMPULAN}

Berdasarkan analaisis Maya Index, Dusun Tegalrejo dan Dusun Krajan Kidul memiliki risiko rendah sebagai tempat perkembangbiakan nyamuk Aedes aegypti. Angka kepadatan jentik di Dusun Tegalrejo masuk dalam skala 3 dan Dusun Krajan Kidul masuk skala 4, sehingga termasuk kategori daerah dengan kepadatan sedang. Keberadaan kontainer Controllable sites sangat berpengaruh terhadap keberadaan jentik sehingga hal itu dapat mempengaruhi status Maya Index dan kepadatan jentik.

Status Maya Index di Dusun Tegalrejo dan Dusun Krajan Kidul termasuk dalam kategori risiko rendah untuk perkembangbiakan nyamuk Aedes aegypti sebaiknya tetap dipertahankan dan angka kepadatan jentik di kedua dusun sebaiknya dikendalikan dengan cara menggerakkan masyarakat untuk mengelola lingkungan khususnya keberadaan kontainer dengan melakukan kegiatan PSN 3M Plus setiap satu minggu sekali yaitu meningkatkan frekuensi pengurasan bak mandi setiap 3 hari sekali, menutup semua tempat penampungan air, dan mendaur ulang barang bekas seperti kaleng bekas dan sejenisnya ke bank sampah. Penggerakan jumantik sebaiknya dilakukan di Dusun Tegalrejo dan Dusun Krajan Kidul untuk melakukan pemantauan jentik berkala pada kontainer di dalam rumah yang terkendali 
(controllable container) dan menggerakkan tindakan PSN masyarakat dalam mengelola lingkungan sekitar yang dapat menjadi tempat perkembangbiakan nyamuk Aedes aegypti.

\section{DAFTAR PUSTAKA}

Ariva, L., Oginawati, K. 2013. Identifikasi Densitiy Figure dan Pengendalian Vektor Demam Berdarah pada Kelurahan Cicadas Bandung. Bandung: Institut Teknologi Bandung. Astuti, E.P., Prasetyowati, H., Ginanjar, A. 2016. Risiko Penularan Demam Berdarah Dengue berdasarkan Maya Indeks dan Indeks Entomologi di Kota Tangerang Selatan Banten. Media Litbangkes, Vol. 26 No. 4: 211-218

Direktorat Jenderal PP\&PL. 2012. Petunjuk Teknis Pemberantasan Sarang Nyamuk (PSN DBD) oleh Juru Pemantau Jentik (Jumantik). Jakarta: Kementerian Kesehatan.

Direktorat Jenderal PP\&PL. 2014. Situasi Demam Berdarah Dengue di Indonesia. Jakarta: Pusat Data dan Informasi Kementerian Kesehatan RI.

Dhewantara, P.W., Dinata, A. 2015. Analisis Risiko Dengue Berbasis Maya Index pada Rumah Penderita DBD di Kota Banjar. Balaba, Vol. 11 No. 01 : 1 8.[https://DOI:10.22435/balaba.v11i1 .4148.1-8]

Dinata, A., Dhewantara,P.W. 2012. Karakteristik Lingkungan Fisik, Biologi, dan Sosial di Daerah Endemis DBD Kota Banjar. Jurnal Ekologi Kesehatan Vol.11, No. 4: 315-326.

Pratamawati, D.A. 2012. Peran Juru Pemantau Jentik dalam Sistem Kewaspadaan Dini Demam Berdarah Dengue di Indonesia. Jurnal Kesehatan Masyarakat Nasional Vol.6, No. 6.

Purnama, S.G., Baskoro, T. 2012. Maya Index dan Kepadatan Larva Aedes aegypti terhadap Infeksi Dengue. Makara, Kesehatan, Vol. 16, No.2 : 57-64.
Rokhmawanti, N., Martini., Ginandjar, P. 2015. Hubungan Maya Index dengan Kejadian Demam Berdarah Dengue Di Kelurahan Tegalsari Kota Tegal. Jurnal Kesehatan Masyarakat Vol.3 No. 1. pp 162-170.

Sigarlaki, I.T., Pijoh, V.D., Tuda, J.S. 2016. Gambaran Indeks Maya pada Rumah Penderita Demam Berdarah Dengue di Kelurahan Kombos Barat Kecamatan Singkil Tahun 2015. Jurnal $e$ Biomedik (eBm), Vol. 4, No.1.

Soegijanto. 2006. Demam Berdarah Dengue. Surabaya: Airlangga University Press.

Sukana, B. 1993. Pemberantasan Vektor DBD di Indonesia. Media Litbangkes Vol. III No.01/1993.

Taviv, Y., Saikhu, A., Sitorus, H. 2010. Pengendalian DBD Melalui Pemanfaatan Pemamntau Jentik dan Ikan Cupang di Kota Palembang. Buletin Penelitian Kesehatan, Vol. 38, No.4 : 198-207.

Wati, W.E. 2009. Beberapa Faktor yang Berhubungan dengan Kejadian Demam Berdarah Dengue (DBD) diKelurahan Ploso Kecamatan Pacitan. Skripsi. Surakarta: Universitas Muhammadiyah.

Widagdo,L., Husodo, B.T., Bhinuri. 2008. Kepadatan Jentik Aedes aegypti sebagai Indikator Keberhasilan PSN (3 M Plus) di Kelurahan Srondol Wetan Semarang. Makara Kesehatan, Vol.12, No. 1: 13-19. 